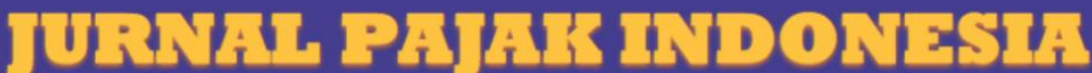

( Indonesian Tax Journal)

www.jurnal.stan.ac.id/index.php/JPI

\section{ASPEK HUKUM TINDAKAN MENTERI KEUANGAN DALAM PENERBITAN KEPUTUSAN PENCEGAHAN}

\author{
Yadhy Cahyady \\ Jurusan Pajak, Politeknik Keuangan Negara STAN
}

cahyavi@gmail.com

\section{INFORMASI ARTIKEL}

Diterima Pertama

[30082019]

Dinyatakan Diterima

[23092019]

KATA KUNCl:

Keputusan Pencegahan, Penagihan Pajak, Penagihan Piutang Negara, Sengketa Pajak

\section{KLASIFIKASI JEL:}

K41

\begin{abstract}
Under his line of work, the minister of finance can issue prevention decisions on Indonesian citizens and foreign nationals who will leave Indonesian territory. Prevention conducted by the minister of finance by the position of the minister of finance as a fiscal manager to collect taxes and receivables. Prevention in the collection of state receivables is charged to the guarantor of the debt, shareholders, and heirs who have received an inheritance from the guarantor of the debt. Against preventive decisions in the context of tax collection, legal remedies can be made in the form of a lawsuit to the tax court. As for the prevention decision in the context of collecting state receivables, legal remedies can be made in the form of administrative efforts, namely objections and appeals at the administrative courts.
\end{abstract}

\section{ABSTRAK}

Menteri Keuangan sesuai bidang tugasnya, dapat menerbitkan keputusan Pencegahan terhadap warga negara Indonesia maupun warga negara asing yang akan keluar wilayah Indonesia. Pencegahan yang dilakukan oleh Menteri Keuangan, sesuai kedudukan Menteri Keuangan selaku pengelolaan fiskal, yaitu dalam rangka penagihan pajak dan piutang Negara. Pencegahan dalam rangka penagihan pajak dikenakan terhadap Penanggung Pajak, sedangkan Pencegahan dalam rangka penagihan piutang Negara dikenakan kepada Penanggung Hutang, Penjamin Hutang, Pemegang Saham, dan Ahli Waris yang telah menerima warisan dari Penanggung Hutang. Terhadap keputusan Pencegahan dalam rangka penagihan pajak, dapat dilakukan upaya hukum berupa gugatan ke Pengadilan Pajak. Adapun terhadap keputusan Pencegahan dalam rangka penagihan piutang Negara, dapat dilakukan upaya hukum berupa Upaya Administratif yaitu Keberatan dan Banding, serta gugatan ke Pengadilan Tata Usaha Negara. 


\section{PENDAHULUAN}

\subsection{Latar Belakang}

Terhadap warga negara Indonesia berlaku prinsip bahwa setiap warga negara Indonesia berhak untuk keluar atau masuk wilayah Indonesia, melalui pemeriksaan yang dilakukan oleh Pejabat Imigrasi di tempat pemeriksaan Imigrasi. Namun, berdasarkan alasan tertentu dan untuk jangka waktu tertentu, warga negara Indonesia dapat dicegah keluar dari wilayah Indonesia. Demikian juga halnya untuk warga negara asing yang akan keluar wilayah Indonesia, maka harus memenuhi persyaratan tertentu, antara lain tidak termasuk dalam daftar Pencegahan.

Menurut Kamus Besar Bahasa Indonesia, Cegah diartikan dicegah untuk melakukan kegiatan perjalanan ke luar negeri, dan sebagainya; dikenai larangan. Sedangkan dalam Undang-Undang Nomor 6 Tahun 2011 Tentang Keimigrasian, Pencegahan adalah larangan sementara terhadap orang untuk keluar dari wilayah Indonesia berdasarkan alasan keimigrasian atau alasan lain yang ditentukan oleh undang-undang. Pencegahan tersebut dilaksanakan oleh Menteri Hukum dan HAM atau Pejabat Imigrasi yang ditunjuk berdasarkan:

a. hasil pengawasan Keimigrasian dan keputusan Tindakan Administratif Keimigrasian;

b. Keputusan Menteri Keuangan dan Jaksa Agung sesuai dengan bidang tugasnya masing-masing dan ketentuan peraturan perundang-undangan;

c. permintaan Kepala Kepolisian Negara Republik Indonesia sesuai dengan ketentuan peraturan perundang-undangan;

d. perintah Ketua Komisi Pemberantasan Korupsi sesuai dengan ketentuan peraturan perundangundangan;

e. permintaan Kepala Badan Narkotika Nasional sesuai dengan ketentuan peraturan perundangundangan; dan/atau

f. keputusan, perintah, atau permintaan pimpinan kementerian/lembaga lain yang berdasarkan undang-undang memiliki kewenangan Pencegahan.

Pencegahan ditetapkan dengan keputusan tertulis oleh pejabat yang berwenang, memuat sekurang-kurangnya:

a. Nama, jenis kelamin, tempat dan tanggal lahir atau umur, serta foto yang dikenai Pencegahan;

b. Alasan Pencegahan; dan

c. Jangka waktu Pencegahan.

Dalam keadaan yang mendesak pejabat yang memiliki kewenangan Pencegahan, dapat meminta secara langsung kepada Pejabat Imigrasi tertentu
Halaman 40

untuk melakukan Pencegahan. Keadaan mendesak ini, ditujukan untuk mencegah orang yang diduga melakukan tindak pidana atau melakukan pelanggaran akan melarikan diri keluar negeri. Orang yang akan dicegah dikhawatirkan diduga pada saat itu telah berada di tempat pemeriksaan Imigrasi untuk keluar negeri, sebelum keputusan Pencegahan ditetapkan.

Menteri Hukum dan HAM atau Pejabat Imigrasi yang ditunjuk, memasukkan identitas orang yang dikenai keputusan Pencegahan ke dalam daftar Pencegahan, sehingga Pejabat Imigrasi wajib menolak orang yang dikenai Pencegahan keluar wilayah Indonesia. Jangka waktu Pencegahan berlaku paling lama 6 (enam) bulan dan setiap kali dapat diperpanjang paling lama 6 (enam) bulan. Dalam hal tidak ada keputusan perpanjangan masa Pencegahan, maka Pencegahan berakhir demi hukum.

Pencegahan akan berakhir karena:

a. Jangka waktu yang ditetapkan telah habis;

b. Dicabut berdasarkan keputusan tertulis Menteri Hukum dan HAM atau pejabat yang berwenang menetapkan Pencegahan;

c. Dicabut oleh pejabat yang menetapkan Pencegahan berdasarkan Putusan Pengadilan Tata Usaha Negara yang berkekuatan hukum tetap; atau

d. Berdasarkan putusan pengadilan yang berkekuatan hukum tetap yang menyatakan bebas atas perkara yang menjadi alasan Pencegahan.

Terkait tindakan Menteri Keuangan dalam menetapkan keputusan Pencegahan, hal ini berkaitan dengan masalah keuangan Negara. Berdasarkan Undang-Undang Nomor 17 Tahun 2003 Tentang Keuangan Negara, Presiden selaku Kepala Pemerintahan memegang kekuasaan pengelolaan keuangan negara sebagai bagian dari kekuasaan pemerintahan. Kekuasaan atas pengelolaan keuangan negara digunakan untuk mencapai tujuan bernegara. Kekuasaan ini oleh Presiden antara lain dikuasakan kepada Menteri Keuangan, selaku pengelola fiskal dan Wakil Pemerintah dalam kepemilikan kekayaan negara yang dipisahkan. Dalam hal ini, Menteri Keuangan sebagai pembantu Presiden dalam bidang keuangan pada hakikatnya adalah Chief Financial Officer (CFO) Pemerintah Republik Indonesia.

Dalam rangka pelaksanaan kekuasaan atas pengelolaan fiskal tersebut, Menteri Keuangan mempunyai tugas antara lain sebagai berikut:

- melaksanakan pemungutan pendapatan Negara yang telah ditetapkan dengan Undang-Undang, terdiri atas penerimaan pajak termasuk pungutan 
bea masuk dan cukai, penerimaan bukan pajak, dan hibah;

- melaksanakan fungsi Bendahara Umum Negara, diantaranya berwenang melakukan penagihan piutang Negara.

Dalam Undang-Undang Nomor 1 Tahun 2004 Tentang Perbendaharaan Negara, yang dimaksud Piutang Negara adalah jumlah uang yang wajib dibayar kepada Pemerintah Pusat dan/atau hak Pemerintah Pusat yang dapat dinilai dengan uang sebagai akibat perjanjian atau akibat lainnya berdasarkan peraturan perundang-undangan yang berlaku atau akibat lainnya yang sah.

Penerbitan keputusan Pencegahan yang dilakukan oleh Menteri Keuangan merupakan salah satu upaya dalam penagihan pajak dan piutang Negara, sesuai bidang tugas yang dimilikinya selaku pengelola fiskal. Namun, agar pelaksanaan Pencegahan tidak sewenang-wenang, maka pelaksanaan Pencegahan oleh Menteri Keuangan sebagai upaya penagihan pajak dan piutang Negara tersebut diberikan syarat-syarat, baik yang bersifat kuantitatif, yakni harus memenuhi penagihan pajak dan piutang Negara dalam jumlah tertentu, maupun yang bersifat kualitatif, yakni diragukan iktikad baiknya dalam melunasi, sehingga Pencegahan hanya dilaksanakan secara sangat selektif dan hati-hati.

\subsection{Rumusan Masalah}

Bertitik tolak dari uraian latar belakang di atas, maka yang menjadi isu hukum sebagai permasalahan dalam penulisan ini adalah sebagai berikut:

- Sejauhmana kewenangan yang dimiliki Menteri Keuangan dalam menerbitkan keputusan Pencegahan?

- Upaya hukum apakah yang dapat dilakukan terhadap keputusan Pencegahan yang diterbitkan oleh Menteri Keuangan?

\subsection{Tujuan Penelitian}

Berdasarkan permasalahan yang telah diuraikan di atas, maka yang menjadi tujuan dalam penulisan ini adalah sebagai berikut:

- Untuk mengkaji dan menganalisis kewenangan yang dimiliki Menteri Keuangan dalam menerbitkan keputusan Pencegahan.

- Untuk mengkaji dan menganalisis upaya hukum yang dapat dilakukan terhadap keputusan Pencegahan yang diterbitkan oleh Menteri Keuangan.

\section{KERANGKA TEORI}

\subsection{Keputusan Pencegahan Sebagai Keputusan Tata} Usaha Negara
Halaman 41

Undang-Undang Nomor 5 Tahun 1986 Tentang Peradilan Tata Usaha Negara sebagaimana telah beberapa kali diubah terakhir kali dengan UndangUndang Nomor 51 Tahun 2009, menyatakan bahwa yang dimaksud Keputusan Tata Usaha Negara adalah suatu penetapan tertulis yang dikeluarkan oleh Badan atau Pejabat Tata Usaha Negara yang berisi tindakan hukum Tata Usaha Negara yang berdasarkan peraturan perundang-undangan yang berlaku, yang bersifat konkret, individual, dan final, yang menimbulkan akibat hukum bagi seseorang atau badan hukum perdata.

Bersifat konkret, artinya objek yang diputuskan dalam Keputusan Tata Usaha Negara itu tidak abstrak, tetapi berwujud, tertentu atau dapat ditentukan.

Bersifat individual artinya Keputusan Tata Usaha Negara itu tidak ditujukan untuk umum, tetapi tertentu baik alamat maupun hal yang dituju. Kalau yang dituju itu lebih dari seorang, tiap-tiap nama orang yang terkena keputusan itu disebutkan.

Bersifat final artinya sudah definitif dan karenanya dapat menimbulkan akibat hukum. Keputusan yang masih memerlukan persetujuan instansi atasan atau instansi lain belum bersifat final karenanya belum dapat menimbulkan suatu hak atau kewajiban pada pihak yang bersangkutan.

Dengan berlakunya Undang-Undang Nomor 30 Tahun 2014 Tentang Administrasi Pemerintahan, Keputusan Tata Usaha Negara sebagaimana dimaksud dalam Undang-Undang Nomor 5 Tahun 1986 Tentang Peradilan Tata Usaha Negara sebagaimana telah diubah dengan Undang-Undang Nomor 9 Tahun 2004 dan Undang-Undang Nomor 51 Tahun 2009 harus dimaknai sebagai:

a. Penetapan tertulis yang juga mencakup tindakan faktual;

b. Keputusan Badan dan/atau Pejabat Tata Usaha Negara di lingkungan eksekutif, legislatif, yudikatif, dan penyelenggara Negara lainnya;

c. Berdasarkan ketentuan perundang-undangan dan AUPB;

d. Bersifat final dalam arti luas;

e. Keputusan yang berpotensi menimbulkan akibat hukum; dan/atau

f. Keputusan yang berlaku bagi warga Negara.

Dalam Undang-Undang Nomor 6 Tahun 2011 Tentang Keimigrasian, Pencegahan dilaksanakan oleh Menteri Hukum dan HAM atau Pejabat Imigrasi yang ditunjuk antara lain berdasarkan Keputusan Menteri Keuangan sesuai dengan bidang tugasnya dan ketentuan peraturan perundang-undangan.

Kewenangan Menteri Keuangan dalam menerbitkan keputusan Pencegahan dimaksud, 
merupakan Atribusi karena diatur dalam UndangUndang Nomor 6 Tahun 2011 Tentang Keimigrasian. Atribusi menurut Undang-Undang Nomor 30 Tahun 2014 tentang Administrasi Pemerintahan adalah pemberian kewenangan kepada badan dan/atau pejabat pemerintahan yang lebih tinggi oleh UndangUndang Dasar Republik Indonesia 1945 atau UndangUndang.

\subsection{Upaya Hukum Dalam Peradilan Tata Usaha Negara}

Ada beberapa upaya hukum yang dapat ditempuh oleh para pihak dalam penyelesaian sengketa Tata Usaha Negara, baik terhadap putusan pengadilan yang belum mempunyai kekuatan hukum tetap maupun terhadap putusan pengadilan yang sudah mempunyai kekuatan hukum tetap.

Upaya hukum yang dapat ditempuh terhadap putusan pengadilan yang belum mempunyai kekuatan hukum tetap atau yang dikenal dengan dengan sebutan upaya hukum biasa, terdiri dari:

- perlawanan

- banding

- kasasi

Sedangkan upaya hukum terhadap putusan pengadilan yang telah mempunyai kekuatan hukum tetap atau yang dikenal dengan sebutan upaya hukum istimewa atau upaya hukum luar biasa, terdiri dari:

- $\quad$ peninjauan kembali (request civil)

- $\quad$ perlawanan pihak ketiga (derden verzet)

\section{METODE PENELITIAN}

Dalam penelitian ini dibutuhkan data yang akurat yang dapat diperoleh melalui prosedur penelitian sebagai berikut :

\subsection{Metode Pendekatan}

Metode pendekatan yang digunakan dalam penelitian ini adalah metode pendekatan yuridis normatif, karena penelitian ini merupakan penelitian hukum yang membahas tentang aspek hukum atas tindakan Menteri Keuangan dalam menerbitkan keputusan Pencegahan.

\subsection{Spesifikasi Penelitian}

Spesifikasi penelitian yang dipakai adalah spesifikasi penelitian deskripsi analisis. Dikatakan deskripsi analisis karena dengan penelitian ini diharapkan mampu memberi gambaran atau uraian secara rinci, sistematis dan menyeluruh mengenai aspek hukum atas tindakan Menteri Keuangan dalam menerbitkan keputusan Pencegahan.

\subsection{Jenis Data}

Dalam penelitian ini digunakan data sekunder berupa : a. Bahan hukum primer yaitu peraturan perundangundangan yang berhubungan dengan materi yang diangkat.

b. Bahan hukum sekunder yaitu buku teks yang berhubungan dengan materi yang diangkat.

c. Bahan hukum tertier yaitu Kamus Besar Bahasa Indonesia.

\subsection{Metode Pengumpulan Data}

Dalam penelitian ini, metode pengumpulan datanya berdasarkan data sekunder yang diperoleh melalui studi kepustakaan/studi dokumenter. Studi kepustakaan/dokumenter ini dilakukan untuk mencari konsepsi-konsepsi, teori-teori, pendapat-pendapat atau penemuan-penemuan yang membahas mengenai aspek hukum atas tindakan Menteri Keuangan dalam menerbitkan keputusan Pencegahan yang diperoleh dari buku-buku, peraturan perundangundangan dan tulisan-tulisan lainnya yang kemudian dituangkan dalam bentuk dokumentasi.

\subsection{Analisis Data}

Data yang telah dikumpulkan melalui kegiatan studi dokumenter selanjutnya dianalisis dan disusun secara sistematis dengan menggunakan logika berpikir dari deduktif ke induktif.

\section{HASIL PENELITIAN}

4.1. Kewenangan Menteri Keuangan Dalam Penerbitan Keputusan Pencegahan

a. Kewenangan Penerbitan Keputusan Pencegahan Dalam Rangka Penagihan Pajak

Bahwa Negara Republik Indonesia adalah negara hukum berdasarkan Pancasila dan Undang-Undang Dasar 1945, bertujuan mewujudkan tata kehidupan negara dan bangsa yang adil dan sejahtera, aman, tenteram, dan tertib, serta menjamin kedudukan hukum yang sama bagi warga masyarakat. Untuk mencapai tujuan dimaksud, pembangunan nasional yang dilaksanakan secara berkesinambungan dan berkelanjutan serta merata di seluruh tanah air memerlukan biaya besar yang harus digali terutama dari sumber kemampuan sendiri.

Dalam rangka kemandirian dimaksud, peran masyarakat dalam pemenuhan kewajiban di bidang perpajakan perlu terus ditingkatkan dengan mendorong kesadaran, pemahaman, dan penghayatan bahwa pajak adalah sumber utama pembiayaan negara dan pembangunan nasional serta merupakan salah satu kewajiban kenegaraan sehingga setiap anggota masyarakat wajib berperan aktif dalam melaksanakan sendiri kewajiban perpajakannya. 
Dalam pelaksanaan peraturan perundangundangan perpajakan sering terdapat utang pajak yang tidak dilunasi oleh Wajib Pajak sebagaimana mestinya, sehingga memerlukan tindakan penagihan yang mempunyai kekuatan hukum yang memaksa.

Dalam Undang-Undang Nomor 19 Tahun 1997 Tentang Penagihan Pajak Dengan Surat Paksa sebagimana telah diubah dengan Undang-Undang Nomor 19 Tahun 2000, diatur bahwa Wajib Pajak adalah orang pribadi atau badan yang menurut peraturan perundang-undangan perpajakan ditentukan untuk melakukan kewajiban perpajakan, termasuk pemungut pajak atau pemotong pajak tertentu. Adapun Penanggung Pajak adalah orang pribadi atau badan yang bertanggung jawab atas pembayaran pajak, termasuk wakil yang menjalankan hak dan memenuhi kewajiban Wajib Pajak menurut ketentuan peraturan perundang-undangan perpajakan.

Penagihan Pajak merupakan serangkaian tindakan agar Penanggung Pajak melunasi utang pajak dan biaya penagihan pajak dengan menegur atau memperingatkan, melaksanakan penagihan seketika dan sekaligus, memberitahukan Surat Paksa, mengusulkan pencegahan, melaksanakan penyitaan, melaksanakan penyanderaan, menjual barang yang telah disita.

Dalam hal penagihan pajak, tindakan Pencegahan hanya dapat dilakukan terhadap Penanggung Pajak yang mempunyai jumlah utang pajak sekurangkurangnya Rp. 100.000.000,- (seratus juta rupiah) dan diragukan iktikad baiknya dalam melunasi utang pajak.

Pencegahan dalam penagihan pajak hanya dapat dilakukan berdasarkan keputusan Pencegahan yang diterbitkan oleh Menteri Keuangan atas permintaan Pejabat yang berwenang atau atasan Pejabat yang bersangkutan. Keputusan Pencegahan dimaksud disampaikan kepada Penanggung Pajak yang dikenakan Pencegahan, Menteri Hukum dan HAM, Pejabat yang memohon Pencegahan, atasan Pejabat yang bersangkutan, dan Kepala Daerah setempat.

Pencegahan dapat dilaksanakan terhadap beberapa orang sebagai Penanggung Pajak Wajib Pajak Badan atau ahli waris, dan Pencegahan terhadap Penanggung Pajak ini tidak mengakibatkan dihapusnya utang pajak dan terhentinya pelaksanaan penagihan pajak. Pelunasan utang pajak oleh Penanggung Pajak merupakan salah satu tujuan penting dilakukannya Pencegahan.

\section{b. Kewenangan Penerbitan Keputusan Pencegahan Dalam Rangka Penagihan Piutang Negara}

Dalam Kamus Besar Bahasa Indonesia, yang dimaksud piutang adalah: 1 uang yang dipinjamkan (yang dapat ditagih dari seseorang); utang-piutang, uang yang dipinjam dari orang lain dan yang dipinjamkan kepada orang lain; 2 tagihan uang perusahaan kepada para pelanggan yang diharapkan akan dilunasi dalam waktu paling lama satu tahun sejak tanggal keluarnya tagihan. Adapun menurut Peraturan Menteri Keuangan Nomor 240/PMK.06/2016 Tentang Pengurusan Piutang Negara, yang dimaksud Piutang Negara adalah jumlah uang yang wajib dibayar kepada Negara berdasarkan suatu peraturan, perjanjian atau sebab apapun.

Piutang Negara pada tingkat pertama diselesaikan sendiri oleh Instansi Pemerintah termasuk Badan Layanan Umum (BLU)/Badan Layanan Umum Daerah (BLUD), Lembaga Negara, Komisi Negara, Badan Hukum lainnya yang dibentuk dengan peraturan perundang-undangan, atau Badan Usaha Milik Negara (BUMN)/Badan Usaha Milik Daerah (BUMD) yang menyalurkan dana yang berasal dari Instansi Pemerintah melalui pola channeling atau risk sharing sesuai dengan ketentuan peraturan perundang-undangan.

Dalam hal penyelesaian Piutang Negara tidak berhasil, Instansi Pemerintah dimaksud wajib menyerahkan pengurusan Piutang Negara kepada Panitia Cabang.

Panitia Urusan Piutang Negara yang selanjutnya disingkat PUPN adalah suatu Panitia interdepartemental sebagaimana dimaksud dalam Undang-Undang Nomor 49 Prp. Tahun 1960 Tentang Panitia Urusan Piutang Negara, yang bertanggungjawab kepada Menteri Keuangan. PUPN mempunyai tugas melaksanakan pengurusan Piutang Negara yang berasal dari instansi pemerintah dan badan usaha yang secara langsung atau tidak langsung dikuasai Negara berdasarkan suatu peraturan, perjanjian atau sebab apapun, dimana pelaksanaan keputusan PUPN diselenggarakan oleh unit organisasi di lingkungan Kementerian Keuangan yang menangani bidang Piutang Negara.

Selanjutnya dalam Peraturan Presiden Republik Indonesia Nomor 89 Tahun 2006 Tentang Panitia Urusan Piutang Negara diatur bahwa PUPN terdiri dari PUPN Pusat yang berkedudukan di Jakarta dan PUPN Cabang yang berkedudukan di lbu Kota Provinsi, kecuali ditentukan lain oleh Menteri Keuangan. Keanggotaan PUPN Pusat terdiri dari:

a. Wakil dari Kementerian Keuangan, yang terdiri dari:

- Direktur Jenderal yang membidangi pengurusan Piutang Negara sebagai Ketua; 
- Direktur di lingkungan Direktorat Jenderal yang membidangi pengurusan Piutang Negara sebagai Sekretaris;

- Kepala Biro Hukum sebagai Anggota.

b. Wakil dari Kepolisian Negara Republik Indonesia sebagai Anggota, dalam hal ini dijabat oleh Direktur II Ekonomi dan Khusus pada Badan Reserse dan Kriminal; dan

c. Wakil dari Kejaksaan Agung sebagai Anggota, dalam hal ini dijabat oleh Direktur Pemulihan dan Perlindungan Hak pada Jaksa Agung Muda Bidang Perdata dan Tata Usaha Negara.

Adapun keanggotaan PUPN Cabang terdiri dari:

a. Wakil dari Kementerian Keuangan terdiri dari Kepala Kantor Wilayah sebagai Ketua dan/atau Kepala Kantor Pelayanan yang menangani pengurusan Piutang Negara sebagai Sekretaris;

b. Wakil dari Kepolisian Daerah sebagai Anggota yang diajukan oleh Kepala Kepolisian Daerah atau pejabat yang berwenang kepada Menteri Keuangan;

c. Wakil dari Kejaksaan Tinggi sebagai Anggota yang diajukan oleh Kepala Kejaksaan Tinggi atau pejabat yang berwenang kepada Menteri Keuangan; dan

d. Wakil dari Pemerintah Daerah sebagai Anggota yang diajukan oleh Gubernur atau pejabat yang berwenang kepada Menteri Keuangan.

Penyerahan pengurusan Piutang Negara disampaikan secara tertulis disertai resume dan dokumen kepada Panitia Cabang melalui Kantor Pelayanan yang menangani pengurusan Piutang Negara yang wilayah kerjanya meliputi tempat kedudukan Penyerah Piutang. Piutang Negara tersebut terdiri atas hutang pokok, bunga, denda, ongkos, dan/atau beban lainnya sesuai perjanjian atau peraturan atau putusan pengadilan.

Dalam hal berkas penyerahan telah memenuhi persyaratan dan dari hasil penelitian berkas dapat dibuktikan adanya dan besarnya Piutang Negara, Panitia Cabang menerima penyerahan pengurusan Piutang Negara dengan menerbitkan Surat Penerimaan Pengurusan Piutang Negara (SP3N), yaitu surat yang diterbitkan oleh Panitia, berisi pernyataan menerima penyerahan pengurusan Piutang Negara dari Penyerah Piutang. Sejak SP3N diterbitkan, pengurusan Piutang Negara beralih kepada Panitia Cabang dan penyelenggaraannya dilakukan oleh Kantor Pelayanan yang menangani pengurusan Piutang Negara.

Penagihan atas Piutang Negara tersebut dilakukan terhadap Penanggung Hutang yaitu badan dan/atau orang yang berhutang menurut peraturan,

\section{Halaman 44}

perjanjian atau sebab apapun, termasuk badan dan/atau orang yang menjamin penyelesaian seluruh hutang Penanggung Hutang. Penjamin Hutang dalam hal ini adalah badan dan/atau orang yang menjamin penyelesaian sebagian atau seluruh hutang Penanggung Hutang.

Dalam hal penagihan Piutang Negara, Pencegahan dilakukan terhadap:

a. Penanggung Hutang;

b. Penjamin Hutang;

c. Pemegang Saham;

d. Ahli waris yang telah menerima warisan dari Penanggung Hutang.

Pencegahan tersebut hanya dapat dilakukan setelah SP3N diterbitkan dan dilaksanakan dengan memperhatikan efektivitas dan efisiensi. Pencegahan dalam rangka penagihan Piutang Negara dapat dilakukan dalam hal:

a. Sisa Hutang

1. Lebih dari Rp. 500.000.000,- (lima ratus juta rupiah); atau

2. Kurang dari Rp. 500.000.000,- (lima ratus juta rupiah) tetapi objek pencegahan sering bepergian keluar wilayah Republik Indonesia; dan

b. Objek Pencegahan beriktikad tidak baik.

Objek Pencegahan dapat dikategorikan sering ke luar wilayah Republik Indonesia, jika selama kurun waktu 12 (dua belas) bulan objek Pencegahan paling sedikit 2 (dua) kali keluar wilayah Republik Indonesia. Kesimpulan bahwa objek Pencegahan sering bepergian ke luar wilayah Republik Indonesia dapat diperoleh Kantor Pelayanan yang menangani pengurusan Piutang Negara dari paspor objek Pencegahan, pengakuan objek Pencegahan, informasi dari instansi berwenang, Penyerah Piutang dan/atau dari sumber lainnya.

Adapun objek Pencegahan dapat dikategorikan beriktikad tidak baik dalam hal:

a. tidak pernah atau jarang memenuhi panggilan Kantor Pelayanan yang menangani pengurusan Piutang Negara;

b. belum pernah membayar atau pernah membayar dalam jumlah relatif kecil dibanding sisa hutangnya;

c. menunda-nunda pembayaran tanpa alasan yang sah; dan/atau

d. bergaya hidup mewah. Kesimpulan objek Pencegahan bergaya hidup mewah dapat diperoleh dari hasil penelitian lapangan, informasi dari Penyerah Piutang, dan/atau informasi dari pihak lain. 
Dalam jangka waktu Pencegahan atau perpanjangan Pencegahan, dapat diberikan izin ke luar wilayah Republik Indonesia oleh Direktur Jenderal yang membidangi pengurusan Piutang Negara atas nama Menteri Keuangan, dengan tidak mengurangi masa pencegahan. Izin ke luar wilayah Republik Indonesia diberikan berdasarkan pertimbangan bahwa objek Pencegahan:

a. menjalankan tugas negara atau mewakili kepentingan negara di forum internasional;

b. menjalankan ibadah haji;

c. memerlukan perawatan atau pengobatan kesehatan ke luar wilayah Republik Indonesia yang didukung oleh rekomendasi dokter ahli di Indonesia;

d. melakukan kerjasama dengan mitra luar negeri untuk kegiatan usaha dalam rangka menyelesaikan hutangnya; atau

e. memerlukan pergi ke luar wilayah Republik Indonesia karena alasan kemanusiaan. Alasan kemanusiaan sebagaimana dimaksud antara lain objek Pencegahan membesuk atau mendampingi orang tua/suami/istri/anak yang memerlukan pengobatan/perawatan.

Masa Pencegahan berakhir dalam hal:

a. Pencegahan dicabut, dalam hal:

- Piutang Negara dinyatakan lunas;

- Pengurusan Piutang Negara dinyatakan selesai atau dikembalikan; atau

- objek Pencegahan telah meninggal dunia.

b. Pencegahan berakhir demi hukum, dalam hal:

- jangka waktu Pencegahan berakhir dan tidak ada perpanjangan; atau

- terdapat putusan pengadilan yang berkekuatan hukum tetap yang menyatakan bebas atas perkara yang menjadi alasan Pencegahan.

Usul penetapan Pencegahan, perpanjangan Pencegahan, pencabutan Pencegahan, atau pemberian izin keluar wilayah Republik Indonesia diajukan oleh Kepala Kantor Pelayanan yang menangani pengurusan Piutang Negara melalui Kepala Kantor Wilayah kepada Direktur Jenderal yang membidangi pengurusan Piutang Negara.

Keputusan Pencegahan, perpanjangan Pencegahan, dan pencabutan Pencegahan ditetapkan secara tertulis oleh Direktur Jenderal yang membidangi pengurusan Piutang Negara atas nama Menteri Keuangan.

Keputusan mengenai perpanjangan Pencegahan ditetapkan sebelum jangka waktu Pencegahan berakhir sedangkan keputusan mengenai pemberian izin ke luar wilayah Republik Indonesia dalam jangka waktu Pencegahan dilakukan dengan menetapkan keputusan tentang perubahan keputusan Pencegahan atau perpanjangan Pencegahan. Keputusan Pencegahan, perpanjangan Pencegahan, pencabutan Pencegahan, dan izin ke luar wilayah Republik Indonesia disampaikan antara lain kepada Menteri Hukum dan HAM dan objek Pencegahan.

Terkait penetapan Pencegahan secara tertulis oleh Direktur Jenderal yang membidangi pengurusan Piutang Negara atas nama Menteri Keuangan, pelimpahan tersebut sebagaimana diatur dalam Keputusan Menteri Keuangan Nomor 347/KMK.01/2008 Tentang Pelimpahan Wewenang Kepada Pejabat Eselon I di Lingkungan Departemen Keuangan Untuk dan Atas Nama Menteri Keuangan menandatangani Surat dan atau Keputusan Menteri Keuangan.

Adanya pelimpahan wewenang dalam hal penerbitan keputusan Pencegahan dari Menteri Keuangan kepada Direktur Jenderal Kekayaan Negara tersebut merupakan Mandat. Dalam Undang-Undang Nomor 30 Tahun 2014 Tentang Administrasi Pemerintahan, yang dimaksud dengan Mandat adalah pelimpahan kewenangan dari badan dan/atau pejabat pemerintahan yang lebih tinggi kepada badan dan/atau pejabat pemerintahan yang lebih rendah dengan tanggung jawab dan tanggung gugat tetap berada pada pemberi mandat.

Namun pelimpahan wewenang dimaksud, seharusnya diatur dalam Undang-Undang Dasar Republik Indonesia 1945 dan/atau Undang-Undang, mengingat Menteri Keuangan memperoleh kewenangannya berdasarkan Atribusi. Hal ini sebagaimana diatur dalam Undang-Undang Nomor 30 Tahun 2014 Tentang Administrasi Pemerintahan, bahwa kewenangan Atribusi tidak dapat didelegasikan, kecuali diatur di dalam UndangUndang Dasar Republik Indonesia 1945 dan/atau Undang-Undang.

4.2. Upaya Hukum Yang Dapat Ditempuh Atas Penerbitan Keputusan Pencegahan

\section{a. Gugatan Ke Pengadilan Pajak Terhadap Keputusan Pencegahan Dalam Rangka Penagihan Pajak}

Dalam Undang-Undang Nomor 48 Tahun 2009 Tentang Kekuasaan Kehakiman, dinyatakan bahwa Kekuasaan Kehakiman adalah kekuasaan negara yang merdeka untuk menyelenggarakan peradilan guna menegakkan hukum dan keadilan berdasarkan Pancasila dan Undang-Undang Dasar Negara Republik Indonesia Tahun 1945, demi terselenggaranya Negara Hukum Republik Indonesia. 
Kekuasaan kehakiman dilakukan oleh sebuah Mahkamah Agung dan badan peradilan yang berada di bawahnya dalam lingkungan peradilan umum, lingkungan peradilan agama, lingkungan peradilan militer, lingkungan peradilan tata usaha negara, dan oleh sebuah Mahkamah Konstitusi. Dalam salah satu lingkungan peradilan yang berada di bawah Mahkamah Agung dapat dibentuk Pengadilan khusus.

Pengadilan Khusus adalah pengadilan yang mempunyai kewenangan untuk memeriksa, mengadili dan memutus perkara tertentu yang hanya dapat dibentuk dalam salah satu lingkungan badan peradilan yang berada di bawah Mahkamah Agung yang diatur dalam undang-undang. Yang dimaksud dengan pengadilan khusus antara lain adalah pengadilan anak, pengadilan niaga, pengadilan hak asasi manusia, pengadilan tindak pidana korupsi, pengadilan hubungan industrial dan pengadilan perikanan yang berada di lingkungan peradilan umum, serta pengadilan pajak yang berada di lingkungan peradilan tata usaha negara.

Dalam hal ini, peradilan tata usaha negara berwenang memeriksa, mengadili, memutus, dan menyelesaikan sengketa tata usaha negara sesuai dengan ketentuan peraturan perundang-undangan. Adapun Pengadilan Pajak yang merupakan pengadilan khusus di lingkungan peradilan tata usaha adalah badan peradilan yang melaksanakan kekuasaan kehakiman bagi Wajib Pajak atau Penanggung Pajak yang mencari keadilan terhadap Sengketa Pajak.

Dalam Undang-Undang Nomor 14 Tahun 2002 Tentang Pengadilan Pajak, yang dimaksud Sengketa Pajak adalah sengketa yang timbul dalam bidang perpajakan antara Wajib Pajak atau Penangung Pajak dengan Pejabat yang berwenang sebagai akibat dikeluarkannya keputusan yang dapat diajukan banding atau gugatan kepada Pengadilan Pajak berdasarkan Peraturan Perundang-undangan perpajakan, termasuk gugatan atas pelaksanaan penagihan berdasarkan Undang-Undang Penagihan Pajak dengan Surat Paksa.

Pengadilan Pajak mempunyai tugas dan wewenang memeriksa dan memutus Sengketa Pajak, dimana Pengadilan Pajak merupakan pengadilan tingkat pertama dan terakhir dalam memeriksa dan memutus Sengketa Pajak.

Undang-Undang Nomor 6 Tahun 1983 Tentang Ketentuan Umum dan Tata Cara Perpajakan sebagaimana telah beberapa kali diubah terakhir kali dengan Undang-Undang Nomor 16 Tahun 2009, mengatur bahwa gugatan oleh Wajib Pajak atau Penanggung Pajak terhadap keputusan pencegahan
Halaman 46

dalam rangka penagihan pajak, hanya dapat diajukan kepada Badan Peradilan Pajak.

Gugatan adalah upaya hukum yang dapat dilakukan Wajib Pajak atau Penanggung Pajak terhadap pelaksanaan penagihan pajak atau terhadap keputusan yang dapat diajukan gugatan berdasarkan Peraturan Perundang-undangan perpajakan yang berlaku.

Gugatan diajukan secara tertulis dalam Bahasa Indonesia kepada Pengadilan Pajak. Gugatan dapat diajukan oleh penggugat, ahli warisnya, seorang pengurus, atau kuasa hukumnya dengan disertai alasan-alasan yang jelas, mencantumkan tanggal diterima, pelaksanaan penagihan, atau Keputusan yang digugat dan dilampiri salinan dokumen yang digugat. Gugatan tidak menunda atau menghalangi dilaksanakannya penagihan pajak atau kewajiban perpajakan.

Jangka waktu untuk mengajukan gugatan terhadap keputusan Pencegahan adalah 30 (tiga puluh) hari sejak tanggal diterima Keputusan yang digugat. Jangka waktu tersebut tidak mengikat apabila jangka waktu dimaksud tidak dapat dipenuhi karena keadaan di luar kekuasaan penggugat. Perpanjangan jangka waktu adalah 14 (empat belas) hari terhitung sejak berakhirnya keadaan di luar kekuasaan penggugat.

Pengadilan Pajak meminta Surat Tanggapan atas Surat Gugatan kepada tergugat dalam jangka waktu 14 (empat belas) hari sejak tanggal diterima Surat Gugatan. Tergugat menyerahkan Surat Tanggapan dalam jangka waktu 1 (satu) bulan sejak tanggal dikirim permintaan Surat Tanggapan. Penggugat dapat menyerahkan Surat Bantahan kepada Pengadilan Pajak dalam jangka waktu 30 (tiga puluh) hari sejak tanggal diterima salinan Surat Tanggapan.

Putusan Pengadilan Pajak dapat berupa:

a. menolak;

b. mengabulkan sebagian atau seluruhnya;

c. menambah Pajak yang harus dibayar;

d. tidak dapat diterima;

e. membetulkan kesalahan tulis dan/atau kesalahan hitung; dan/atau

f. membatalkan

Putusan Pengadilan Pajak langsung dapat dilaksanakan dengan tidak memerlukan lagi keputusan pejabat yang berwenang kecuali peraturan perundang-undangan mengatur lain. Putusan Pengadilan Pajak harus dilaksanakan oleh Pejabat yang berwenang dalam jangka waktu 30 (tiga puluh) hari terhitung sejak tanggal diterima putusan. Pejabat yang tidak melaksanakan putusan Pengadilan Pajak 
dalam jangka waktu dimaksud dikenakan sanksi sesuai dengan ketentuan kepegawaian yang berlaku.

Putusan Pengadilan Pajak merupakan putusan akhir dan mempunyai kekuatan hukum tetap. Terhadap putusan dimaksud tidak dapat lagi diajukan gugatan, banding, atau kasasi. Pihak-pihak yang bersengketa dapat mengajukan peninjauan kembali atas putusan Pengadilan Pajak kepada Mahkamah Agung

Permohonan peninjauan kembali tidak menangguhkan atau menghentikan pelaksanaan putusan Pengadilan Pajak. Permohonan peninjauan kembali hanya dapat diajukan berdasarkan alasanalasan sebagai berikut:

a. Apabila putusan Pengadilan Pajak didasarkan pada suatu kebohongan atau tipu muslihat pihak lawan yang diketahui setelah perkaranya diputus atau didasarkan pada bukti-bukti yang kemudian oleh hakim pidana dinyatakan palsu;

b. Apabila terdapat bukti tertulis baru yang penting dan bersifat menentukan, yang apabila diketahui pada tahap persidangan di Pengadilan Pajak akan menghasilkan putusan yang berbeda;

c. Apabila telah dikabulkan suatu hal yang tidak dituntut atau lebih dari pada yang dituntut;

d. Apabila mengenai suatu bagian dari tuntutan belum diputus tanpa dipertimbangkan sebabsebabnya; atau

e. Apabila terdapat suatu putusan yang nyata-nyata tidak sesuai dengan ketentuan peraturan perundang-undangan yang berlaku.

Pengajuan permohonan peninjauan kembali dilakukan dalam jangka waktu paling lambat 3 (tiga) bulan terhitung sejak:

a. diketahuinya kebohongan atau tipu muslihat atau sejak putusan Hakim pengadilan pidana memperoleh kekuatan hukum tetap;

b. ditemukan surat-surat bukti yang hari dan tanggal ditemukannya harus dinyatakan di bawah sumpah dan disahkan oleh pejabat yang berwenang;

c. putusan dikirim.

b. Gugatan ke Pengadilan Tata Usaha Negara Terhadap Keputusan Pencegahan Dalam Rangka Penagihan Piutang Negara

\section{1) Upaya Administratif}

Pejabat yang memiliki kewenangan Pencegahan bertanggung jawab atas keputusan, permintaan, dan perintah Pencegahan yang dibuatnya. Setiap orang yang dikenai Pencegahan dapat mengajukan keberatan kepada pejabat yang mengeluarkan keputusan Pencegahan. Pengajuan keberatan dilakukan secara tertulis disertai dengan alasan dan
Halaman 47

disampaikan dalam jangka waktu berlakunya masa Pencegahan. Namun demikian, pengajuan keberatan tidak menunda pelaksanaan Pencegahan. Yang dimaksud dengan mengajukan keberatan adalah upaya hukum yang diberikan kepada orang yang terkena Pencegahan untuk melakukan pembelaan diri atas Pencegahan yang dikenakan kepada dirinya.

Upaya keberatan dalam hal ini merupakan bagian dari upaya administratif yang dapat ditempuh oleh orang yang terkena Pencegahan. Menurut UndangUndang Nomor 30 Tahun 2014 Tentang Administrasi Pemerintahan, Upaya Administratif adalah proses penyelesaian sengketa yang dilakukan dalam lingkungan Administrasi Pemerintahan sebagai akibat dikeluarkannya Keputusan dan/atau Tindakan yang merugikan. Upaya Administratif terdiri atas:

a. keberatan; dan

b. banding.

Upaya Administratif dimaksud tidak menunda pelaksanaan Keputusan dan/atau Tindakan, kecuali:

a. ditentukan lain dalam undang-undang; dan

b. menimbulkan kerugian yang lebih besar.

a) Keberatan

Terkait keberatan atas penerbitan Pencegahan, Badan dan/atau Pejabat Pemerintahan berwenang dalam hal ini Menteri Keuangan, menyelesaikan keberatan atas keputusan Pencegahan yang diajukan oleh orang yang terkena Pencegahan. Keputusan Pencegahan dapat diajukan keberatan dalam waktu paling lama 21 (dua puluh satu) hari kerja sejak diumumkannya Keputusan tersebut oleh Menteri Keuangan. Keberatan dimaksud diajukan secara tertulis kepada Menteri Keuangan selaku pejabat yang menetapkan Keputusan.

Dalam hal keberatan dimaksud diterima, Menteri Keuangan wajib menetapkan Keputusan sesuai permohonan keberatan. Menteri Keuangan menyelesaikan keberatan paling lama 10 (sepuluh) hari kerja. Dalam hal Menteri Keuangan tidak menyelesaikan keberatan dalam jangka waktu dimaksud, keberatan atas penerbitan keputusan Pencegahan dianggap dikabulkan.

Keberatan yang dianggap dikabulkan, ditindaklanjuti dengan penetapan Keputusan sesuai dengan permohonan keberatan oleh Menteri Keuangan, dimana Menteri Keuangan wajib menetapkan Keputusan sesuai dengan permohonan paling lama 5 (lima) hari kerja setelah berakhirnya tenggang waktu dimaksud.

\section{b) Banding}

Dalam hal orang yang terkena Pencegahan tidak menerima atas penyelesaian keberatan oleh Menteri Keuangan, orang yang terkena Pencegahan dapat 
mengajukan banding kepada Atasan Menteri Keuangan, dalam hal ini Presiden. Keputusan dapat diajukan banding dalam waktu paling lama 10 (sepuluh) hari kerja sejak keputusan upaya keberatan diterima. Banding sebagaimana dimaksud diajukan secara tertulis kepada Presiden selaku Atasan Pejabat yang menetapkan Keputusan.

Dalam hal banding sebagaimana dimaksud dikabulkan, Menteri Keuangan wajib menetapkan Keputusan sesuai dengan permohonan banding. Presiden selaku Atasan Pejabat yang menetapkan Keputusan menyelesaikan banding paling lama 10 (sepuluh) hari kerja. Dalam hal Presiden selaku Atasan Pejabat yang menetapkan Keputusan tidak menyelesaikan banding dalam jangka waktu dimaksud, keberatan dianggap dikabulkan.

Menteri Keuangan wajib menetapkan Keputusan sesuai dengan permohonan paling lama 5 (lima) hari kerja setelah berakhirnya tenggang waktu dimaksud. Dalam hal orang yang terkena Pencegahan tidak menerima atas penyelesaian banding oleh Presiden selaku Atasan Pejabat yang menetapkan Keputusan, maka orang yang terkena Pencegahan tersebut dapat mengajukan gugatan sengketa Administrasi Pemerintahan ke Pengadilan Tata Usaha Negara.

\section{2) Gugatan Ke Pengadilan Tata Usaha Negara}

Peradilan Tata Usaha Negara adalah salah satu pelaku kekuasaan kehakiman bagi rakyat pencari keadilan terhadap sengketa Tata Usaha Negara. Kekuasaan kehakiman di lingkungan Peradilan Tata Usaha Negara berpuncak pada Mahkamah Agung sebagai Pengadilan Negara Tertinggi. Kekuasaan kehakiman di lingkungan Peradilan Tata Usaha Negara dilaksanakan oleh:

a. Pengadilan Tata Usaha Negara, yang merupakan pengadilan tingkat pertama dan dibentuk dengan Keputusan Presiden;

b. Pengadilan Tinggi Tata Usaha Negara, yang merupakan pengadilan tingkat banding dan dibentuk dengan undang-undang.

Dalam Undang-Undang Nomor 5 Tahun 1986 Tentang Peradilan Tata Usaha Negara sebagaimana telah beberapa kali diubah terakhir kali dengan Undang-Undang Nomor 51 Tahun 2009, yang dimaksud Sengketa Tata Usaha Negara adalah sengketa yang timbul dalam bidang Tata Usaha Negara antara orang atau badan hukum perdata dengan Badan atau Pejabat Tata Usaha Negara, baik di tingkat pusat maupun di daerah, sebagai akibat dikeluarkannya Keputusan Tata Usaha Negara, termasuk sengeketa kepegawaian berdasarkan peraturan perundang-undangan yang berlaku.

\section{Halaman 48}

Dalam hal suatu Badan atau Pejabat Tata Usaha Negara diberi wewenang oleh atau berdasarkan peraturan perundang-undangan untuk menyelesaikan secara administratif sengketa Tata Usaha Negara tertentu, maka Pengadilan Tata Usaha Negara baru berwenang memeriksa, memutus, dan menyelesaikan sengketa Tata Usaha Negara jika seluruh upaya administratif yang bersangkutan telah digunakan. Dalam hal ini, sebelum mengajukan gugatan atas keputusan Menteri Keuangan ke Pengadilan Tata Usaha Negara, orang yang terkena Pencegahan harus terlebih dahulu mengajukan upaya administratif berupa keberatan kepada Menteri Keuangan dan banding kepada Presiden selaku atasan Menteri Keuangan.

Selanjutnya, orang yang terkena Pencegahan tersebut dapat mengajukan gugatan tertulis kepada Pengadilan Tata Usaha Negara berisi tuntutan agar keputusan Pencegahan yang disengketakan itu dinyatakan batal atau tidak sah, dengan atau tanpa disertai tuntutan gati rugi dan/atau rehabilitasi.

Alasan-alasan yang dapat digunakan dalam gugatan Tata Usaha Negara adalah:

a. Keputusan Tata Usaha Negara yang digugat itu bertentangan dengan peraturan perundangundangan yang berlaku;

b. Badan atau Pejabat Tata Usaha Negara pada waktu mengeluarkan keputusan telah menggunakan wewenangnya untuk tujuan lain dari maksud diberikannya wewenang tersebut;

c. Badan atau Pejabat Tata Usaha Negara pada waktu mengeluarkan atau tidak mengeluarkan keputusan setelah mempertimbangkan semua kepentingan yang tersangkut dengan keputusan itu seharusnya tidak sampai pada pengambilan atau tidak pengambilan keputusan tersebut.

Berdasarkan Peraturan Mahkamah Agung Nomor 6 Tahun 2018 Tentang Pedoman Penyelesaian Sengketa Administrasi Pemerintahan Setelah Menempuh Upaya Administratif, maka tenggang waktu pengajuan gugatan ke Pengadilan Tata Usaha Negara oleh orang yang terkena Pencegahan, dihitung 90 (sembilan puluh) hari sejak keputusan atas upaya administratif diterima atau diumumkan oleh Badan dan/atau Pejabat administrasi pemerintahan yang menangani penyelesaian upaya administratif. Gugatan dimaksud tidak menunda atau menghalangi dilaksanakannya keputusan Pencegahan yang digugat.

Orang yang terkena Pencegahan selaku penggugat dapat mengajukan permohonan agar pelaksanaan keputusan Pencegahan itu ditunda selama pemeriksaan sengketa Tata Usaha Negara sedang berjalan, sampai ada putusan Pengadilan yang 
memperoleh kekuatan hukum tetap. Permohonan dimaksud dapat diajukan sekaligus dalam gugatan dan dapat diputus terlebih dahulu dari pokok sengketanya. Permohonan penundaan dimaksud dapat dikabulkan hanya apabila terdapat keadaan yang sangat mendesak yang mengakibatkan kepentingan penggugat sangat dirugikan jika keputusan Pencegahan yang digugat itu tetap dilaksanakan. Namun, bisa pula tidak dapat dikabulkan apabila kepentingan umum dalam rangka pembangunan mengharuskan dilaksanakannya keputusan tersebut.

Putusan Pengadilan Tata Usaha Negara dapat berupa:

a. gugatan ditolak;

b. gugatan dikabulkan;

c. gugatan tidak diterima; atau

d. gugatan gugur.

Dalam hal gugatan dikabulkan, maka dalam putusan Pengadilan tersebut dapat ditetapkan kewajiban yang harus dilakukan oleh Badan atau Pejabat Tata Usaha Negara yang mengeluarkan Keputusan Tata Usaha Negara. Kewajiban dimaksud berupa:

a. pencabutan Keputusan Tata Usaha Negara yang bersangkutan; atau

b. pencabutan Keputusan Tata Usaha Negara yang bersangkutan dan menerbitkan Keputusan Tata Usaha Negara yang baru; atau

c. penerbitan Keputusan Tata Usaha Negara.

Hanya putusan Pengadilan yang telah memperoleh kekuatan hukum tetap yang dapat dilaksanakan. Terhadap putusan Pengadilan Tata Usaha Negara dapat dimintakan pemeriksaan banding oleh penggugat atau tergugat kepada Pengadilan Tinggi Tata Usaha Negara. Permohonan pemeriksaan banding diajukan secara tertulis oleh pemohon atau kuasanya yang khusus dikuasakan untuk itu kepada Pengadilan Tata Usaha Negara yang menjatuhkan putusan tersebut dalam tenggang waktu 14 (empat belas) hari setelah putusan Pengadilan itu diberitahukan kepadanya secara sah. Para pihak dapat menyerahkan memori banding dan/atau kontra memori banding serta surat keterangan dan bukti kepada Panitera Pengadilan Tinggi Tata Usaha Negara dengan ketentuan bahwa salinan memori dan/atau kontra memori diberikan kepada pihak lainnya dengan perantaraan Panitera Pengadilan.

Undang-Undang Nomor 14 Tahun 1985 Tentang Mahkamah Agung sebagaimana telah beberapa kali diubah terakhir kali dengan Undang-Undang Nomor 3 Tahun 2009, mengatur bahwa terhadap putusan tingkat terakhir Pengadilan dapat dimohonkan pemeriksaan kasasi kepada Mahkamah Agung. Mahkamah Agung memutus permohonan kasasi terhadap putusan Pengadilan Tingkat Banding atau Tingkat Terakhir dari semua Lingkungan Peradilan. Mahkamah Agung dalam tingkat kasasi membatalkan putusan atau penetapan pengadilan-pengadilan dari semua lingkungan peradilan karena:

a. tidak berwenang atau melampaui batas wewenang;

b. salah menerapkan atau melanggar hukum yang berlaku; atau

c. Ialai memenuhi syarat-syarat yang diwajibkan oleh peraturan perundang-undangan yang mengancam kelalaian itu dengan batalnya putusan yang bersangkutan.

Permohonan kasasi dapat diajukan hanya jika pemohon terhadap perkaranya telah menggunakan upaya hukum banding kecuali ditentukan lain oleh Undang-Undang. Permohonan kasasi dalam perkara Tata Usaha Negara disampaikan secara tertulis atau lisan melalui Panitera Pengadilan Tingkat Pertama yang telah memutus perkaranya, dalam tenggang waktu 14 (empat belas) hari sesudah putusan atau penetapan Pengadilan yang dimaksudkan diberitahukan kepada pemohon.

Apabila tenggang waktu 14 (empat belas) hari tersebut telah lewat tanpa ada permohonan kasasi yang diajukan oleh pihak berperkara, maka pihak yang berperkara dianggap telah menerima putusan. Dalam pengajuan permohonan kasasi pemohon wajib menyampaikan pula memori kasasi yang memuat alasan-alasannya, dalam tenggang waktu 14 (empat belas) hari setelah permohonan yang dimaksud dicatat dalam buku daftar. Pihak lawan berhak mengajukan surat jawaban terhadap memori kasasi kepada Panitera, dalam tenggang waktu 14 (empat belas) hari sejak tanggal diterimanya salinan memori kasasi.

Terhadap putusan Pengadilan yang telah memperoleh kekuatan hukum tetap dapat diajukan permohonan peninjauan kembali kepada Mahkamah Agung. Mahkamah Agung memeriksa dan memutus permohonan peninjauan kembali pada tingkat pertama dan terakhir atas putusan Pengadilan yang telah memperoleh kekuatan hukum tetap. Permohonan peninjauan kembali tidak menangguhkan atau menghentikan pelaksanaan putusan Pengadilan.

Permohonan peninjauan kembali atas putusan yang telah memperoleh kekuatan hukum tetap dapat diajukan hanya berdasarkan alasan-alasan sebagai berikut: 
a. apabila putusan didasarkan pada suatu kebohongan atau tipu muslihat pihak lawan yang diketahui setelah perkaranya diputus atau didasarkan pada bukti-bukti yang kemudian oleh hakim pidana dinyatakan palsu;

b. apabila setelah perkara diputus, ditemukan suratsurat bukti yang bersifat menentukan yang pada waktu perkara diperiksa tidak dapat ditemukan;

c. apabila telah dikabulkan suatu hal yang tidak dituntut atau lebih dari pada yang dituntut;

d. apabila mengenai sesuatu bagian dari tuntutan belum diputus tanpa dipertimbangkan sebabsebabnya;

e. apabila antara pihak-pihak yang sama mengenai suatu soal yang sama, atas dasar yang sama oleh Pengadilan yang sama atau sama tingkatnya telah diberikan putusan yang bertentangan satu dengan yang lain; atau

f. apabila dalam suatu putusan terdapat suatu kekhilafan Hakim atau suatu kekeliruan yang nyata.

Tenggang waktu pengajuan permohonan peninjauan kembali adalah 180 (seratus delapan puluh) hari:

a. sejak diketahui kebohongan atau tipu muslihat atau sejak putusan Hakim pidana memperoleh kekuatan hukum tetap, dan telah diberitahukan kepada para pihak yang berperkara;

b. sejak ditemukan surat-surat bukti, yang hari serta tanggal ditemukannya harus dinyatakan di bawah sumpah dan disahkan oleh pejabat yang berwenang;

c. sejak putusan memperoleh kekuatan hukum tetap dan telah diberitahukan kepada para pihak yang berperkara; atau

d. sejak putusan yang terakhir dan bertentangan itu memperoleh kekuatan hukum tetap dan telah diberitahukan kepada pihak yang berperkara.

Permohonan peninjauan kembali diajukan oleh pemohon secara tertulis dengan menyebutkan sejelas-jelasnya alasan yang dijadikan dasar permohonan itu dan dimasukkan di kepaniteraan Pengadilan Tata Usaha Negara yang memutus perkara dalam tingkat pertama. Apabila pemohon tidak dapat menulis, maka ia menguraikan permohonannya secara lisan di hadapan Ketua Pengadilan Tata Usaha Negara yang memutus perkara dalam tingkat pertama atau hakim yang ditunjuk oleh Ketua Pengadilan yang akan membuat catatan tentang permohonan tersebut. Tenggang waktu bagi pihak lawan untuk mengajukan jawabannya adalah 30 (tiga puluh) hari setelah tanggal diterimanya salinan permohonan peninjauan kembali.

\section{KESIMPULAN DAN SARAN}

\subsection{Kesimpulan}

1. Terkait kewenangan Menteri Keuangan atas penerbitan keputusan Pencegahan, dapat disimpulkan sebagai berikut:

a. Menteri Keuangan mempunyai kewenangan berdasarkan Atribusi dari Undang-Undang Nomor 6 Tahun 2011 Tentang Keimigrasian, untuk menerbitkan keputusan Pencegahan dalam rangka penagihan pajak dan piutang Negara, sesuai bidang tugasnya selaku pengelola fiskal. Dalam rangka penagihan pajak, keputusan Pencegahan ditetapkan secara tertulis oleh Menteri Keuangan, sedangkan dalam rangka penagihan piutang Negara, keputusan Pencegahan ditetapkan secara tertulis oleh Direktur Jenderal yang membidangi pengurusan Piutang Negara atas nama Menteri Keuangan, berdasarkan pelimpahan wewenang berupa Mandat.

b. Dalam hal penagihan pajak, tindakan Pencegahan hanya dapat dilakukan terhadap Penanggung Pajak yang mempunyai jumlah utang pajak sekurang-kurangnya $\mathrm{Rp}$. 100.000.000,- (seratus juta rupiah) dan diragukan iktikad baiknya dalam melunasi utang pajak. Sedangkan tindakan Pencegahan dalam rangka penagihan piutang Negara dapat dilakukan dalam hal:

1) Sisa Hutang

a) Lebih dari Rp. 500.000.000,- (lima ratus juta rupiah); atau

b) Kurang dari Rp. 500.000.000,- (lima ratus juta rupiah) tetapi objek pencegahan sering bepergian keluar wilayah Republik Indonesia; dan

2) Objek Pencegahan beriktikad tidak baik.

2. Terhadap keputusan Pencegahan yang diterbitkan oleh Menteri Keuangan, orang yang terkena Pencegahan dapat mengajukan upaya hukum sebagai berikut:

- Mengajukan gugatan ke Pengadilan Pajak. Upaya hukum ini dilakukan terhadap keputusan Pencegahan yang terkait dengan penagihan pajak; atau

- Mengajukan gugatan ke Pengadilan Tata Usaha Negara, setelah melalui Upaya Administratif terlebih dahulu berupa Keberatan dan Banding. Upaya hukum ini dilakukan terhadap keputusan Pencegahan yang terkait dengan penagihan piutang Negara. 


\subsection{Saran}

1. Mengingat dalam penerbitan keputusan Pencegahan terdapat perbedaan, dimana untuk keputusan Pencegahan dalam rangka penagihan pajak ditetapkan secara tertulis oleh Menteri Keuangan, sedangkan untuk keputusan Pencegahan dalam rangka penagihan piutang Negara ditetapkan secara tertulis oleh Direktur Jenderal yang membidangi pengurusan Piutang Negara atas nama Menteri Keuangan, maka perlu kiranya perlakuan yang sama berdasarkan peraturan perundang-undangan yang berlaku, dalam hal ini ditetapkan secara tertulis oleh Menteri Keuangan, tanpa dilimpahkan kepada pejabat di bawahnya. Hal ini sebagaimana diatur dalam Undang-Undang Nomor 30 Tahun 2014 tentang Administrasi Pemerintahan, bahwa kewenangan Atribusi tidak dapat didelegasikan, kecuali diatur di dalam Undang-Undang Dasar Republik Indonesia 1945 dan/atau UndangUndang.

2. Selain itu, perlu pula perlakuan yang sama terkait jumlah penagihan pajak dan piutang Negara sebagai salah satu dasar dalam penerbitan keputusan Pencegahan, dimana saat ini tindakan Pencegahan dilakukan terhadap Penanggung Pajak yang mempunyai jumlah utang pajak sekurang-kurangnya Rp. 100.000.000,- (seratus juta rupiah), sedangkan tindakan Pencegahan dalam rangka penagihan piutang Negara dilakukan dalam hal sisa hutang:

a. Lebih dari Rp. 500.000.000,- (lima ratus juta rupiah); atau

b. Kurang dari Rp. 500.000.000,- (lima ratus juta rupiah) tetapi objek pencegahan sering bepergian keluar wilayah Republik Indonesia.

\section{IMPLIKASI DAN KETERBATASAN}

Dari hasil penelitian yang dilakukan, dapat diketahui adanya beberapa perbedaan perlakuan atas penerbitan keputusan Pencegahan dalam rangka penagihan pajak dan piutang Negara. Hal ini menunjukan masih perlunya harmonisasi dan sinkronisasi peraturan sehingga nantinya ada keseragaman perlakuan terhadap hal tersebut.

Adapun keterbatasan dalam penelitian ini, bahwa penelitian masih terfokus pada kegiatan inventarisasi peraturan perundang-undangan yang berkaitan dengan kewenangan Menteri Keuangan dalam penerbitan keputusan Pencegahan.
Buku:

Amiruddin dan Zainal Asikin. (2006). Pengantar Metode Penelitian Hukum. Jakarta: Rajawali Pers.

Bohari, H. (2016). Pengantar Hukum Pajak. Jakarta: Rajawali Pers.

Diantha, I Made Pasek. (2019). Metodologi Penelitian Hukum Normatif Dalam Justifikasi Teori Hukum. Jakarta: Kencana.

Hadjon, Philipus M dan Tatiek Sri Djatmiati. (2005). Argumentasi Hukum. Yogyakarta: Gajah Mada University Press.

Marzuki, Peter Mahmud. (2017). Penelitian Hukum Edisi Revisi. Jakarta: Kencana.

Negara, Tunggul Anshari Setia. (2017). Ilmu Hukum Pajak. Malang: Setara Press.

Ridwan, H.R. (2006). Hukum Administrasi Negara. Jakarta: Rajawali Pers.

Saidi, Muhammad Djafar. (2008). Hukum Keuangan Negara. Jakarta: Rajawali Pers.

Sutrisno, Deddy. (2016). Hakikat Sengketa Pajak. Jakarta: Kencana.

Tjandra, W. Riawan. (2006). Hukum Keuangan Negara. Jakarta: Grasindo.

Peraturan Perundang-undangan:

Undang-Undang Nomor 1 Tahun 2004 Tentang Perbendaharaan Negara.

Undang-Undang Nomor 6 Tahun 1983 tentang Ketentuan Umum dan Tata Cara Perpajakan sebagaimana telah beberapa kali diubah terakhir kali dengan Undang-Undang Nomor 16 Tahun 2009.

Undang-Undang Nomor 19 tahun 1997 tentang Penagihan Pajak Dengan Surat Paksa sebagimana telah diubah dengan Undang-Undang Nomor 19 Tahun 2000.

Undang-Undang Nomor 48 Tahun 2009 Tentang Kekuasaan Kehakiman.

Undang-Undang Nomor 14 Tahun 1985 Tentang Mahkamah Agung sebagaimana telah beberapa kali diubah terakhir kali dengan Undang-Undang Nomor 3 Tahun 2009.

Undang-Undang Nomor 5 Tahun 1986 Tentang Peradilan Tata Usaha Negara sebagaimana telah beberapa kali diubah terakhir kali dengan Undang-Undang Nomor 51 Tahun 2009.

Undang-Undang Nomor 14 tahun 2002 tentang Pengadilan Pajak.

Undang-Undang Nomor 49 Prp. Tahun 1960 Tentang Panitia Urusan Piutang Negara.

\section{DAFTAR PUSTAKA}


Undang-Undang Nomor 30 Tahun 2014 tentang Administrasi Pemerintahan.

Peraturan Pemerintah Nomor 31 Tahun 2013 Tentang Peraturan Pelaksanaan Undang-Undang Nomor 6 Tahun 2011 Tentang Keimigrasian.

Peraturan Mahkamah Agung Nomor 6 Tahun 2018 Tentang Pedoman Penyelesaian Sengketa Administrasi Pemerintahan Setelah Menempuh Upaya Administratif.

Peraturan Presiden Republik Indonesia Nomor 89 Tahun 2006 Tentang Panitia Urusan Piutang Negara.

Peraturan Menteri Keuangan Nomor 240/PMK.06/2016 tentang Pengurusan Piutang Negara.

Keputusan Menteri Keuangan Nomor 347/KMK.01/2008 tentang Pelimpahan Wewenang Kepada Pejabat Eselon I di Lingkungan Departemen Keuangan Untuk dan Atas Nama Menteri Keuangan menandatangani Surat dan atau Keputusan Menteri Keuangan. 